\title{
Activity and Process Stability of Purified Green Pepper (Capsicum annuum) Pectin Methylesterase
}

\author{
Sónia Marília Castro, ${ }^{\dagger}$ Ann Van Loey, ${ }^{\S}$ Jorge AleXandre Saraiva,${ }^{\dagger}$ \\ Chantal Smout, ${ }^{\S}$ and Marc HendrickX $*$,
Department of Chemistry, Universidade de Aveiro, Campus Santiago, 3810-193 Aveiro, Portugal, and Laboratory of Food Technology, Faculty of Applied Bioscience and Engineering, Katholieke Universiteit Leuven, Kasteelpark Arenberg 22, B-3001 Heverlee (Leuven), Belgium

\begin{abstract}
Pectin methylesterase (PME) from green bell peppers (Capsicum annuum) was extracted and purified by affinity chromatography on a CNBr-Sepharose-PMEI column. A single protein peak with pectin methylesterase activity was observed. For the pepper PME, a biochemical characterization in terms of molar mass (MM), isoelectric points ( $\mathrm{p} /$ ), and kinetic parameters for activity and thermostability was performed. The optimum $\mathrm{pH}$ for PME activity at $22{ }^{\circ} \mathrm{C}$ was 7.5 , and its optimum temperature at neutral $\mathrm{pH}$ was between 52.5 and $55.0^{\circ} \mathrm{C}$. The purified pepper PME required the presence of $0.13 \mathrm{M} \mathrm{NaCl}$ for optimum activity. Isothermal inactivation of purified pepper PME in $20 \mathrm{mM}$ Tris buffer $(\mathrm{pH} 7.5)$ could be described by a fractional conversion model for lower temperatures $\left(55-57^{\circ} \mathrm{C}\right)$ and a biphasic model for higher temperatures $\left(58-70^{\circ} \mathrm{C}\right)$. The enzyme showed a stable behavior toward high-pressure/temperature treatments.
\end{abstract}

KEYWORDS: Capsicum annuum; pepper; pectin methylesterase; purification; characterization; thermal and high-pressure stability

\section{INTRODUCTION}

Peppers have become more popular in recent years due to their chemical composition (e.g., vitamins), and a wide variety is nowadays available on the market. Most varieties belong to the Capsicum annuum species, and they can be consumed fresh or processed, as immature (i.e., green) or as mature fruit (i.e., yellow, orange, red), as a spice or as a vegetable, because of their distinct colors, intense taste, and unique flavor. The texture, in particular, the crispness, of peppers is an important quality attribute to consumers. It is known that vegetable texture is closely related to the pectic substances and to activities of pectolytic enzymes (1). Prominent among the enzymes implicated in the softening of fruits and vegetables during ripening are polygalacturonase and pectin methylesterase (PME) due to their relationship with the cell-wall pectic content. Although peppers, like tomatoes, belong to the Solanaceae family, there is little information in the literature on the pectolytic enzymes and their relationship with biochemical cell-wall changes of bell peppers and texture $(2-4)$. One reason such information is lacking is probably due to the anticipated low enzyme activities in peppers, as the texture degradation in peppers is a slow process (2). Nevertheless, PMEs play a central role in texture evolution; the control of its activity, through knowledge of its

* Author to whom correspondence should be addressed (fax +32 163219 60; telephone +3216 3215 72; e-mail Marc.Hendrickx@ agr.kuleuven.ac.be).

Universidade de Aveiro.

$\S$ Katholieke Universiteit Leuven. dependence on parameters such as temperature and $\mathrm{pH}$, is of great practical importance in the food industry for protecting and improving the texture and firmness of several processed fruits and vegetables (5). Thermal processing is still one of the most frequently used methods for food preservation, and one approach to optimize the heat treatment of fruits and vegetables in order to maximize the overall quality is to develop a model considering, among other parameters, the (in)activation kinetics for relevant enzymes to predict quality changes during processing and subsequent storage. PME has been extracted and purified from many different sources and characterized in terms of biochemical properties and thermal stability (e.g., see refs 5-12). In this work, PME was extracted from green peppers and purified by affinity chromatography. The purified pepper PME obtained was biochemically characterized and submitted to thermal and high-pressure inactivation.

\section{MATERIALS AND METHODS}

Materials. Green bell peppers (C. апnиит) were purchased from a local auction (Mechelen, Belgium). Apple pectin [degree of esterification $(\mathrm{DE})=75 \%$ ] was obtained from Fluka Chemicals Co. (Buchs, Switzerland). CNBr-Sepharose 4B resin was purchased from Sigma (St. Louis, MO). All other chemicals were of analytical grade.

Methods. Pectin Methylesterase Purification. PME was extracted from peppers with $0.2 \mathrm{M}$ tris(hydroxymethyl)aminomethane buffer (i.e., Tris buffer) ( $\mathrm{pH} 8.0$ ) with $1 \mathrm{M} \mathrm{NaCl}$, followed by purification by affinity chromatography on a CNBr-Sepharose 4B-PME inhibitor column and finally stored at $-80{ }^{\circ} \mathrm{C}$ in $20 \mathrm{mM}$ Tris buffer ( $\mathrm{pH}$ 7.5) using the procedure as described by Ly-Nguyen et al. (11). 
Pectin Methylesterase Assay. PME activity was measured by continuous recording of titration of carboxyl groups released from a pectin solution using an automatic $\mathrm{pH}$-stat (Metrohm, Switzerland) and $0.01 \mathrm{~N} \mathrm{NaOH}$ solution. Routine assays were performed with a $3.5 \mathrm{mg} /$ $\mathrm{mL}$ apple pectin solution $(\mathrm{DE}=75 \%, 30 \mathrm{~mL})$ containing $0.117 \mathrm{M}$ $\mathrm{NaCl}(\mathrm{pH} 7.0)$ at $22{ }^{\circ} \mathrm{C}$. The activity unit of PME is defined as the amount of enzyme required to release $1 \mu \mathrm{mol}$ of carboxyl groups per minute, under the aforementioned assay conditions.

Protein Determination. Protein concentration was determined using Sigma procedure TPRO-562. Bovine serum albumin (Sigma) was used as a standard.

Gel Electrophoresis. A PhastSystem (Amersham Biosciences, Uppsala, Sweden) was used for both SDS-PAGE and IEF experiments. SDS-PAGE was performed using Fast Gel homogeneous 20\% and PhastGel Tris-tricine SDS buffer strips. Samples were boiled for 5 min at $100{ }^{\circ} \mathrm{C}$ in a buffer containing SDS $(2.5 \%)$ and $\beta$-mercaptoethanol $(5 \%)$. The molecular mass markers were phosphorylase $b(94 \mathrm{kDa})$, bovine serum albumin $(67 \mathrm{kDa})$, ovalbumin $(43 \mathrm{kDa})$, carbonic anhydrase $(30 \mathrm{kDa})$, soybean trypsin inhibitor $(20.1 \mathrm{kDa})$, and lactalbumin $(14.1 \mathrm{kDa})$. The IEF was performed in a Phastgel IEF medium (polyacrylamide gels) in the $\mathrm{pH}$ range of $3-9$, using a calibration kit (Pharmacia) containing 11 proteins with isoelectric points ranging from 9.3 to 3.5 . Gel staining was performed with silver nitrate according to the method of Heuskeshoven and Dernick (13), using the equipment from Pharmacia.

Effect of Pectin and $\mathrm{NaCl}$ Concentration on Pectin Methylesterase Activity. The effect of substrate concentration (apple pectin, $\mathrm{DE}=75 \%$, $30 \mathrm{~mL}$ ) was determined by measuring the activity of purified PME in the presence of various substrate concentrations $(0.10-7.5 \mathrm{mg} / \mathrm{mL})$, with $0.117 \mathrm{M} \mathrm{NaCl}$ at $\mathrm{pH} 7.0$. The $K_{\mathrm{m}}$ and maximum rate $\left(V_{\max }\right)$ were determined by nonlinear regression analysis using the MichaelisMenten equation. The effect of $\mathrm{NaCl}$ concentration on the PME activity was studied in the range of $0-0.3 \mathrm{M} \mathrm{NaCl}$.

Effect of $\mathrm{pH}$ on Pectin Methylesterase Activity. The $\mathrm{pH}$ dependence of the purified pepper PME activity was assayed titrimetrically at $22{ }^{\circ} \mathrm{C}$ with $0.01 \mathrm{~N} \mathrm{NaOH}$ after adjustment of the $\mathrm{pH}$ of the reaction solution to one of the $\mathrm{pH}$ values tested $(3.5-9.0)$. Corrections were made to each experiment for the spontaneous de-esterification of pectin at alkaline conditions.

Effect of Assay Temperature on Pectin Methylesterase Activity. The effect of the assay temperature on the purified pepper PME activity was tested under standard assay conditions $(\mathrm{pH} 7.0)$ with various temperatures. The temperature $\left(22-70{ }^{\circ} \mathrm{C}\right)$ was controlled by means of a circulating water bath. Corrections were made to each experiment for the spontaneous de-esterification of pectin at elevated temperatures. The activation energy $\left(E_{\mathrm{a}}\right)$ of PME-catalyzed pectin de-esterification was calculated using the Arrhenius equation

$$
k=A \exp \left(-E_{\mathrm{a}} / R T\right)
$$

where $k$ is the rate constant, $R$ is the gas constant $\left(8.314 \mathrm{~J} \mathrm{~mol}^{-1} \mathrm{~K}^{-1}\right)$, $A$ is a pre-exponential factor, and $T$ is the temperature $(\mathrm{K})$.

Thermal and Pressure Stability of Purified Pepper Pectin Methylesterase. The thermal stability of purified pepper PME was investigated at $\mathrm{pH} 7.5$ within a temperature range of $22-70{ }^{\circ} \mathrm{C}$. Thermal treatments were performed by immersing glass capillaries (Hirschmann, Germany) with the enclosed enzyme solution, in a temperature-controlled water bath, during $5 \mathrm{~min}$. After the treatments, the capillaries were immediately cooled in ice water. Residual activities of PME were measured within $60 \mathrm{~min}$ of storage at $0{ }^{\circ} \mathrm{C}$. Pressure treatments were conducted in a multivessel high-pressure apparatus (eight vessels of 8 $\mathrm{mL}$ ) (Resato, Roden, The Netherlands). The pressure medium is a glycol-oil mixture (TR-15, Resato). To enclose the enzyme solution, flexible microtubes of $0.3 \mathrm{~mL}$ were used (Elkay, Leuven, Belgium). The microtubes were placed in the pressure vessels, already equilibrated at desired temperature $\left(25\right.$ and $\left.60^{\circ} \mathrm{C}\right)$. Pressure was built slowly $(100$ $\mathrm{MPa} / \mathrm{min}$ ) to minimize temperature increases due to adiabatic heating. After pressure buildup, an equilibrium period of 2 min to allow the temperature to evolve to its desired value was taken into account. After $15 \mathrm{~min}$, the pressure was released, the samples were immediately cooled in an ice-water bath, and the residual activities of PME were measured within $60 \mathrm{~min}$ of storage in ice water.

Thermal Inactivation Kinetics of Purified Pepper Pectin Methylesterase. Thermal inactivation of purified pepper PME was investigated within a temperature range of $55-70{ }^{\circ} \mathrm{C}$ at $\mathrm{pH}$ 7.5. Isothermal treatments were performed in a temperature-controlled water bath using glass capillaries (Hirschmann, Germany) to enclose the enzyme solution. After the treatments, the capillaries were immediately cooled in ice water. Residual activities of PME were measured within $60 \mathrm{~min}$ of storage at $0{ }^{\circ} \mathrm{C}$.

Kinetic Data Analysis. Inactivation of enzymes can often be described by a first-order kinetic model (14). When there are several isozymes present, which show different behavior toward temperature and/or pressure, that is, labile and stable fractions, and both inactivating according to a first-order kinetic model (15-18), a biphasic kinetic model (eq 2) or distinct isozyme model can be used. There is a fast inactivation period followed by a decelerated decay.

$$
\mathrm{N}_{\mathrm{L}} \stackrel{k_{\mathrm{L}}}{\longrightarrow} \mathrm{I}_{\mathrm{L}} \quad \mathrm{N}_{\mathrm{S}} \stackrel{k_{\mathrm{S}}}{\longrightarrow} \mathrm{I}_{\mathrm{S}} \quad A=A_{\mathrm{L}} \exp \left(-k_{\mathrm{L}} t\right)+A_{\mathrm{S}} \exp \left(-k_{\mathrm{S}} t\right)
$$

The subscripts $\mathrm{L}$ and $\mathrm{S}$ indicate labile and stable enzyme fractions, respectively. The residual activity from the labile and stable fractions as well as the inactivation rate constants can be estimated by nonlinear regression analysis. When only the labile fraction inactivates, whereas the activity of the stable fraction does not change with respect to time, a fractional conversion kinetic model should be applied. A fractional conversion model takes into account the residual activity after prolonged thermal and/or pressure treatment (eq 3):

$$
\mathrm{N}+\mathrm{RF} \stackrel{k}{\rightarrow} \mathrm{I}+\mathrm{RF} \quad A=A_{\infty}+\left(A_{0}-A_{\infty}\right) \exp (-k t)
$$

$A_{\infty}$ is the residual activity after prolonged treatment time. The inactivation rate constant $(k)$ and the residual activity $\left(A_{\infty}\right)$ are estimated by nonlinear regression analysis. It should be stressed that for experiments at constant temperature and/or pressure, the heating and/ or pressurizing time should be long enough so that the remaining activity, $A_{\infty}$, is no longer changing with respect to time $(19,20)$. The temperature dependence of inactivation rate constants can be estimated using the Arrhenius model (eq 4)

$$
\ln (k)=\ln \left(k_{0}\right)+\left[\frac{E_{\mathrm{a}}}{R}\left(\frac{1}{T_{0}}-\frac{1}{T}\right)\right]
$$

where $T$ and $T_{0}$ are the absolute temperature $(\mathrm{K})$ and the reference temperature $(\mathrm{K})$, respectively; $k_{0}$ is the rate constant at $T_{0}, E_{\mathrm{a}}$ is the activation energy $\left(\mathrm{kJ} \mathrm{mol}^{-1}\right)$, and $R\left(8.314 \mathrm{~J} \mathrm{~mol}^{-1} \mathrm{~K}^{-1}\right)$ is the universal gas constant. The activation energy can be estimated by linear regression analysis on eq 4.

\section{RESULTS AND DISCUSSION}

Purification of Pepper Pectin Methylesterase by Affinity Chromatography. PME is located in the cell walls of higher plants and is ionically bound to the cell wall. Hence, a high ionic strength buffer is required for extraction from the cell walls (0.2 M Tris buffer, $1 \mathrm{M} \mathrm{NaCl}, \mathrm{pH}$ 8.0). In Figure 1, the elution profile of pepper PME from the affinity column shows that inert proteins were removed with $2 \mathrm{mM} \mathrm{KH}_{2} \mathrm{PO}_{4}$ buffer ( $\mathrm{pH} 6.0$ ) containing $0.5 \mathrm{M} \mathrm{NaCl}$. Purified pepper PME was then eluted with a high ionic strength and high $\mathrm{pH}$ buffer $\left(50 \mathrm{mM} \mathrm{Na}_{2}-\right.$ $\mathrm{CO}_{3}, 1 \mathrm{M} \mathrm{NaCl}, \mathrm{pH} 9.85$ ), and a single peak of proteins and PME activity was obtained. Each replicate purification of the enzyme showed a single protein and activity peak. The PME activity found in the crude extract ( 2.5 units/g of fresh material) was in the range found in previous work on sweet bell peppers at different stages of maturity (2). Purified pepper PME had a maximum activity of 242.5 units/mg of protein corresponding to at least a 10.3-fold enrichment and an overall yield of at 


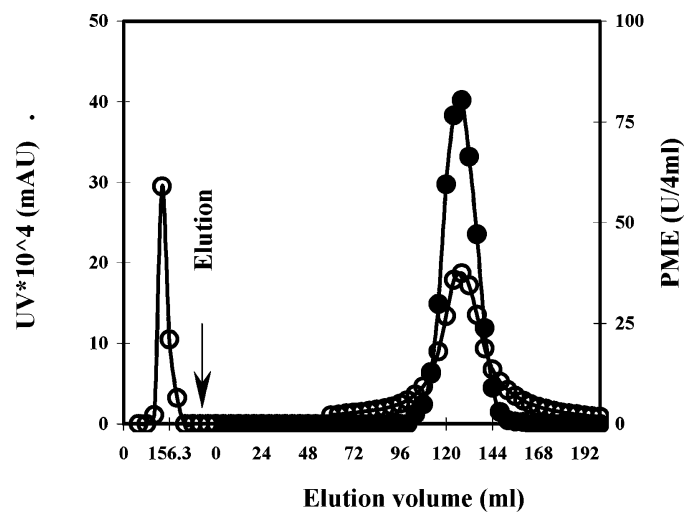

Figure 1. Elution profile of green pepper PME on a PMEI-CNBr-Sepharose 4B column: UV absorbance (measured at $\lambda=280 \mathrm{~nm}$ ) (O); PME activity (๑). Washing solution was $2 \mathrm{mM} \mathrm{KH}_{2} \mathrm{PO}_{4}$ buffer, containing $0.5 \mathrm{M} \mathrm{NaCl}$ at $\mathrm{pH}$ 6.0. The elution buffer was $50 \mathrm{mM} \mathrm{Na}_{2} \mathrm{CO}_{3}$, containing $1 \mathrm{M} \mathrm{NaCl}$ at $\mathrm{pH} 9.85$.

Table 1. Extraction and Purification of Pepper Pectin Methylesterase

\begin{tabular}{lccccc}
\hline & $\begin{array}{c}\text { activity } \\
\text { (units) }\end{array}$ & $\begin{array}{c}\text { protein } \\
(\mathrm{mg})\end{array}$ & $\begin{array}{c}\text { specific activity } \\
\left(\text { units } \mathrm{mg}^{-1}\right)\end{array}$ & $\begin{array}{c}\text { recovery } \\
(\%)\end{array}$ & $\begin{array}{c}\text { purification } \\
\text { factor }\end{array}$ \\
\hline crude extract & 1999 & 84.8 & 23.6 & 100 & 1 \\
purified PME & 417 & 1.72 & 242.5 & 20.9 & 10.3 \\
\hline
\end{tabular}

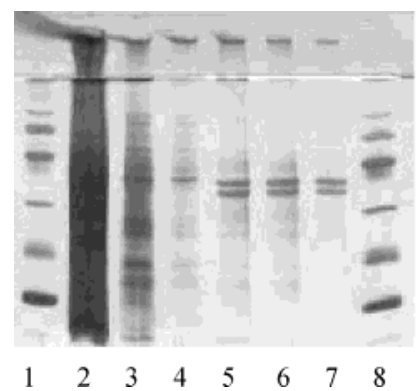

$94.0 \mathrm{kDa}$

$67.0 \mathrm{kDa}$

$43.0 \mathrm{kDa}$

$30.0 \mathrm{kDa}$

$20.1 \mathrm{kDa}$

$14.4 \mathrm{kDa}$

$\begin{array}{llllllll}1 & 2 & 3 & 4 & 5 & 6 & 7 & 8\end{array}$

Figure 2. SDS-PAGE of green pepper PME: (lanes 1 and 8) SDS-PAGE standards; (lanes 2-4) crude green pepper extract; (lanes 5-7) pepper PME after affinity chromatography.

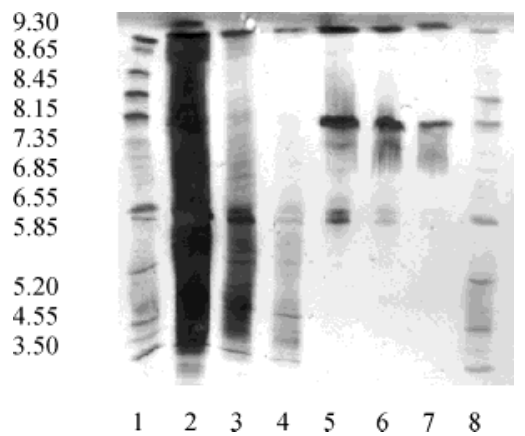

Figure 3. IEF of green pepper PME: (lanes 1 and 8 ) p/ standards; (lanes 2-4) crude extract; (lanes 5-7) pepper PME after affinity chromatography.

least $20.9 \%$, based on the total enzymatic activity of crude extract (Table 1).

On SDS-PAGE, the purified pepper PME produced two bands with identical intensities (Figure 2). After comparison with the electrophoretic mobility of the standard proteins, the bands obtained indicated molecular masses of 33 and $37 \mathrm{kDa}$, which are in the range of other plant PMEs purified from different sources $(5,7-9,21,22)$. On the IEF gel, purified pepper PME showed several bands between 6.0 and 9.3 (Figure 3), of which two were cathodic ( $\mathrm{p} I$ values of 7.9 and 7.5) and two were

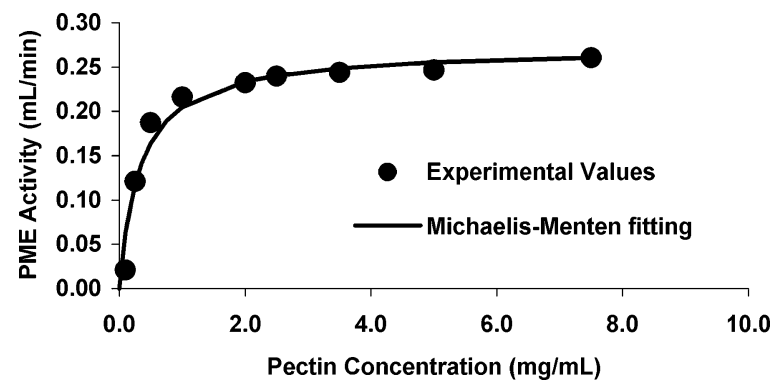

Figure 4. Activity of green pepper PME as a function of substrate concentration. Assay conditions: apple pectin (DE 75\%), pH 7.5, $22^{\circ} \mathrm{C}$, $0.117 \mathrm{M} \mathrm{NaCl}$.

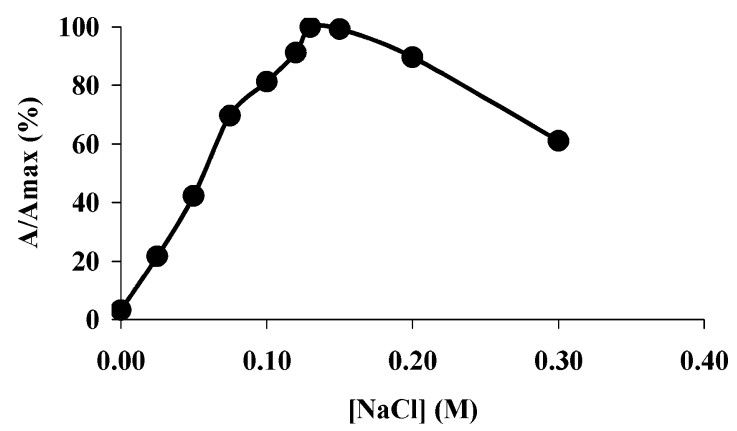

Figure 5. Activity of green pepper PME as a function of salt concentration. Assay conditions: apple pectin (DE 75\%) solution $3.5 \mathrm{mg} / \mathrm{mL}, \mathrm{pH} 7.5$, $22{ }^{\circ} \mathrm{C}$.

anodic ( $\mathrm{p} I$ values of 6.3 and 6.1). There was also observed another band at a $\mathrm{p} I>9.3$ (around 9.6 determined by extrapolation), suggesting that there might be some other forms. Generally, the isoelectric point of plant PMEs is between 7 and 11 , but some acidic forms have also been reported $(6,8,11$, 22).

Effect of Pectin and $\mathrm{NaCl}$ Concentration on Pectin Methylesterase Activity. The activity of pepper PME as a function of apple pectin concentration was investigated (Figure 4). The kinetic parameters $K_{\mathrm{m}}$ and the maximum rate $\left(V_{\max }\right)$ were determined by nonlinear regression analysis as $0.329 \mathrm{mg} / \mathrm{mL}$ and $0.272 \mathrm{~mL} / \mathrm{min}$, respectively. For routine assays (substrate concentration of $3.5 \mathrm{mg} / \mathrm{mL}$ ) the initial rate of the enzyme represented $98 \%$ of the maximum rate. Pepper PME activity, like any other plant $\mathrm{PME}$, depends on the $\mathrm{NaCl}$ concentration in the assay (Figure 5). The activity increased with the salt concentration up to $0.13 \mathrm{M}$, but when the $\mathrm{NaCl}$ level was raised further, the activity decreased gradually. At $0.3 \mathrm{M} \mathrm{NaCl}, \sim 60 \%$ of the activity at optimal $\mathrm{NaCl}$ concentration $(0.13 \mathrm{M})$ was observed. According to this study, pepper PME possesed only $3 \%$ activity in the control assay (no $\mathrm{NaCl}$ added) in comparison to the activity at $0.13 \mathrm{M} \mathrm{NaCl}$. Previous studies on purified apple PME reported also a maximal enzyme activity for 0.13 $\mathrm{M} \mathrm{NaCl}$ at $\mathrm{pH} 7$ (10). The effect of $\mathrm{NaCl}$ on plant PMEs varies considerably, and even PMEs from different varieties of the same fruit have shown different optimum $\mathrm{NaCl}$ concentrations for their maximum activities $(21,23)$. The stimulatory effect of the salt on the pepper PME activity is quite high, with 13-, $25-$, and 30 -fold increases in the activity for $0.05,0.1$, and 0.15 $\mathrm{M}$ of $\mathrm{NaCl}$ concentrations, respectively, as compared to the control.

Effect of pH on Pectin Methylesterase Activity. The study of purified pepper PME activity as a function of $\mathrm{pH}$ reveals (Figure 6) that the activity increases rapidly from 4.5 to 6.5 (79\%). The optimum $\mathrm{pH}$ value of 7.5 is within the optimal $\mathrm{pH}$ range of 7-9 of most plant PMEs from different sources (23). 


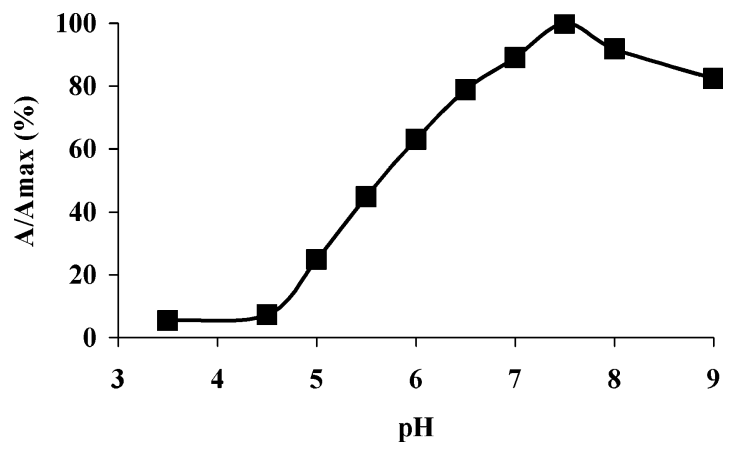

Figure 6. Activity of green pepper PME as a function of $\mathrm{pH}$. Assay conditions: apple pectin (DE 75\%) solution $3.5 \mathrm{mg} / \mathrm{mL}, 22{ }^{\circ} \mathrm{C}, 0.117 \mathrm{M}$ $\mathrm{NaCl}$.

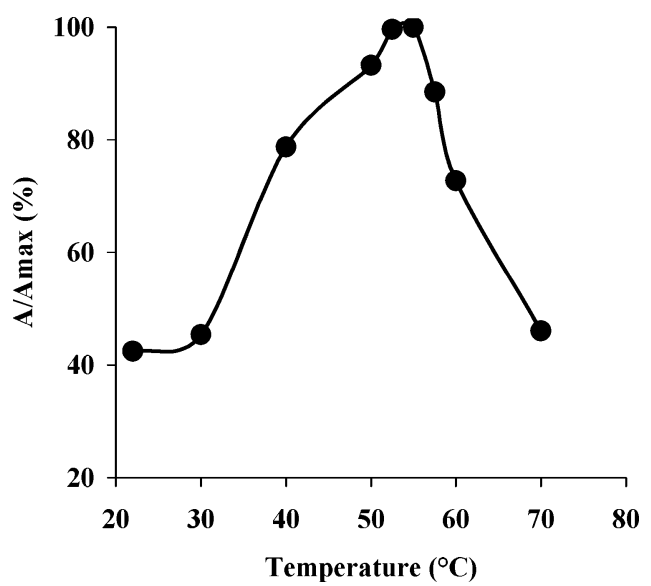

Figure 7. Activity of green pepper PME as a function of temperature. Assay conditions: apple pectin (DE $75 \%$ ) solution $3.5 \mathrm{mg} / \mathrm{mL}, \mathrm{pH} 7.5$, $0.117 \mathrm{M} \mathrm{NaCl}$.

Above $\mathrm{pH}$ 7.5, the PME activity remains relatively high over the range of alkaline $\mathrm{pH}$. At $\mathrm{pH} 9.0$ there is still $83 \%$ of PME activity at optimal $\mathrm{pH}$.

Effect of Temperature on Pectin Methylesterase Activity. The effect of the reaction temperature on PME activity is shown in Figure 7. From 30 to $40{ }^{\circ} \mathrm{C}$, there was a sudden increase in PME activity, up to $79 \%$. Maximal PME activity was observed around $52.5-55^{\circ} \mathrm{C}$. From the slope of the Arrhenius plot (not shown) of the data in Figure 7, the activation energy $\left(E_{\mathrm{a}}\right)$ of pepper PME was estimated to be $22.8 \mathrm{~kJ} \mathrm{~mol}^{-1}$ (5445 cal $\mathrm{mol}^{-1}$ ), from 22 to $55^{\circ} \mathrm{C}$. This value is in agreement with values of 5000, 5600, 5740, 5800, and $6200 \mathrm{cal} \mathrm{mol}^{-1}$, which have been reported for cucumber ionically bound PME (24), orange PME 1 and 2 (25), apple PME (26), and potato PME (27), respectively.

Temperature and Pressure Stability of Purified Pepper Pectin Methylesterase. In Figure 8, relative residual activity is plotted as a function of inactivation temperature. Within the temperature range of inactivation, purified pepper PME was gradually inactivated. At $60{ }^{\circ} \mathrm{C}, 50 \%$ of PME activity was lost after 5 min of treatment, whereas at $68{ }^{\circ} \mathrm{C},>90 \%$ of the PME activity was lost under the same conditions and at $70^{\circ} \mathrm{C}$ purified pepper PME is completely inactivated. Two inactivation phases can be observed (Figure 8). The onset of the first inactivation phase is estimated at $\sim 50-55^{\circ} \mathrm{C}$, and the onset of the second one at $\sim 62{ }^{\circ} \mathrm{C}$. Pressure stability at 25 and $60{ }^{\circ} \mathrm{C}$ of purified pepper PME was screened by pressurizing samples for $15 \mathrm{~min}$ in the pressure range of $400-800 \mathrm{MPa}$ (Figure 9). At $25^{\circ} \mathrm{C}$, there is a slight decrease on the relative residual activity in the pressure range studied, whereas at $60^{\circ} \mathrm{C}$ the PME is quite stable

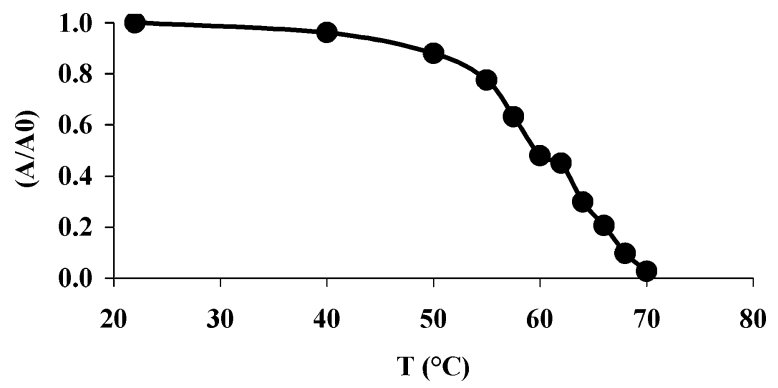

Figure 8. Thermal stability of purified green pepper PME. Residual activity was measured after $5 \mathrm{~min}$ of treatment at different temperatures. Assay conditions: apple pectin (DE 75\%) solution $3.5 \mathrm{mg} / \mathrm{mL}, \mathrm{pH} 7.5,0.117 \mathrm{M}$ $\mathrm{NaCl}$.

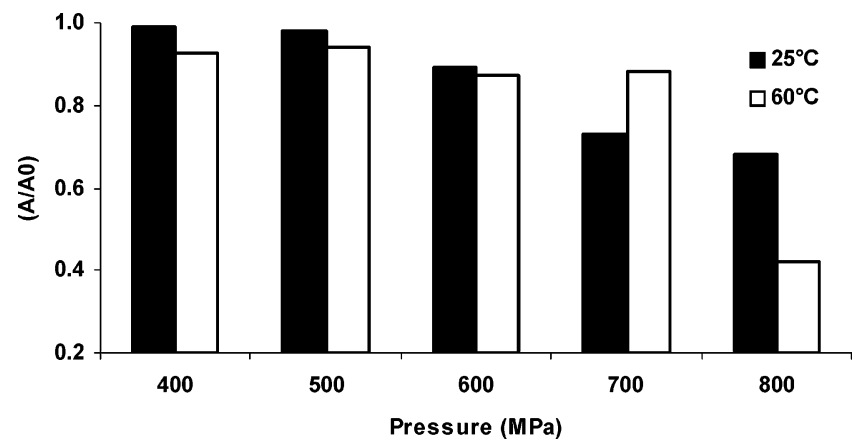

Figure 9. Pressure stability of purified green pepper PME at 25 and $60^{\circ} \mathrm{C}$. Residual activity was measured after $15 \mathrm{~min}$ of treatment. Assay conditions: apple pectin (DE 75\%) solution $3.5 \mathrm{mg} / \mathrm{mL}$, pH 7.5, $0.117 \mathrm{M}$ $\mathrm{NaCl}$.

until $700 \mathrm{MPa}$. This could be due to the effect on the heat labile form of PME at the lower temperature, whereas at the high temperature the heat labile form might already have been inactivated during pressure buildup and in the equilibration period. When the adiabatic effect in the pressure range studied is taken into consideration, the residual PME activity after the 2 min of equilibration for 25 and $60^{\circ} \mathrm{C}$ is already around $90-$ $80 \%$ and $78-42 \%$, respectively, compared to the control at $25^{\circ} \mathrm{C}$ and at atmospheric pressure (data not shown). Crelier et al. (28) concluded that tomato PME was stabilized against thermal denaturation at pressures above atmospheric pressure and up to $500-600 \mathrm{MPa}$. In more recent studies on tomato $\mathrm{PME}$, in either juice or purified form at $\mathrm{pH} 4.4$, the enzyme was revealed to be very pressure-resistant, up to $700 \mathrm{MPa}(29)$. Seyderhelm et al. (30) reported the effect of high pressure on PME for commercial orange PME in Tris buffer ( $\mathrm{pH} \mathrm{7),} \mathrm{at}$ $45^{\circ} \mathrm{C}$. The shortest processing time of 2 min was shown to be sufficient to completely inactivate $\mathrm{PME}$ at $900 \mathrm{MPa}$. A degree of inactivation rate of $58 \%$ was obtained for purified pepper PME after $15 \mathrm{~min}$ of treatment at $800 \mathrm{MPa}$ and $60^{\circ} \mathrm{C}$.

Thermal Inactivation Kinetics of Purified Pepper Pectin Methylesterase. On the basis of results of thermal stability, a detailed kinetic study of thermal inactivation of purified pepper PME dissolved in $20 \mathrm{mM}$ Tris buffer was performed in the range from 55 to $70{ }^{\circ} \mathrm{C}$ at atmospheric pressure. Figure 10A presents the thermal inactivation curves of pepper PME at $\mathrm{pH} 7.5$, in the temperature range from 55 to $57^{\circ} \mathrm{C}$. A fractional conversion model could accurately describe this inactivation behavior, indicating the presence of a temperature-resistant enzyme fraction that is not affected after a prolonged heating at the preset temperatures. The estimated rate constants, $A_{\infty}$ values, and activation energy are given in Table 2. As expected, the inactivation rate constants increase with increasing temperature. 

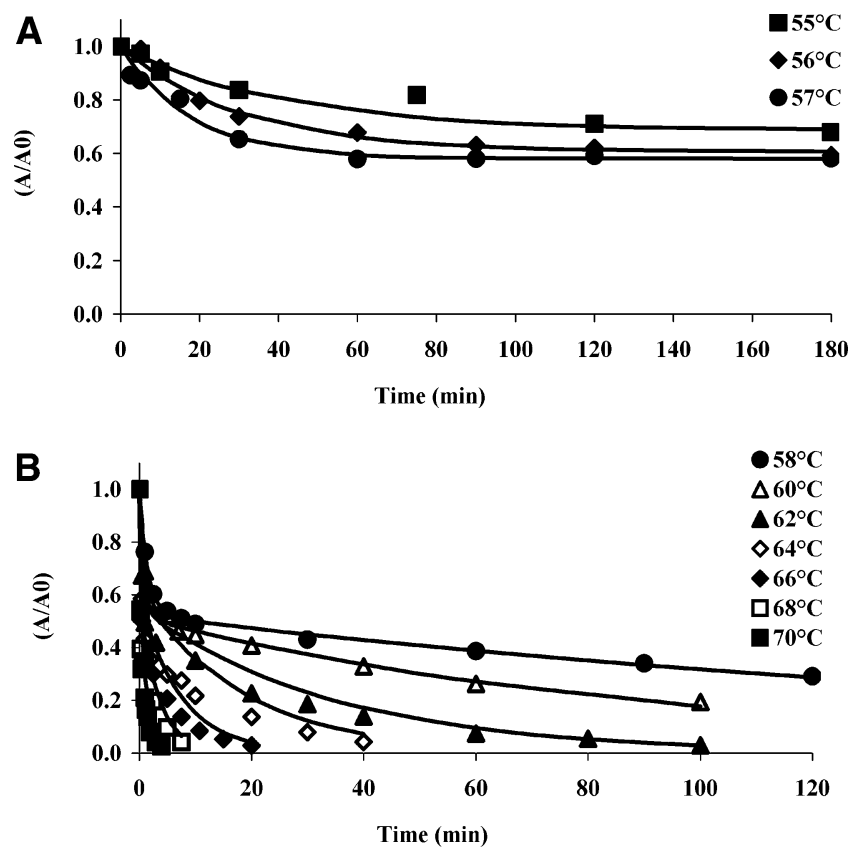

Figure 10. Thermal inactivation of purified green pepper PME dissolved in $20 \mathrm{mM}$ Tris buffer $\left(\mathrm{pH} \mathrm{7.5)}\right.$, for $55-57^{\circ} \mathrm{C}(\mathbf{A})$ and $58-70{ }^{\circ} \mathrm{C}(\mathbf{B})$ temperature ranges.

Table 2. Estimated Kinetic Parameters for Thermal Inactivation of Purified Pepper Pectin Methylesterase in 20 mM Tris Buffer, pH 7.5

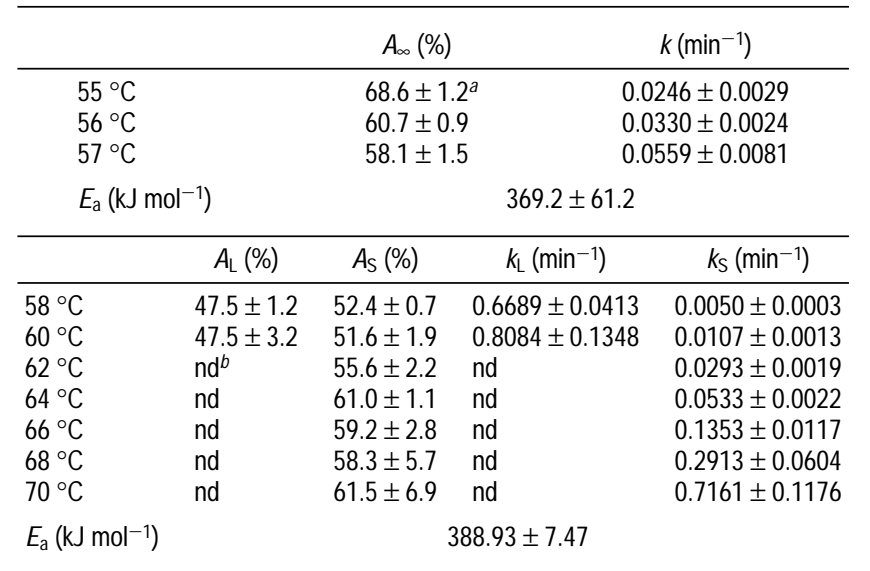

${ }^{a}$ Standard error of regression. ${ }^{b}$ Not determined.

The temperature dependence of the inactivation rate constants in the temperature range $\left(55-57^{\circ} \mathrm{C}\right)$ was estimated by linear regression analysis (eq 4) as $369.2 \mathrm{~kJ} \mathrm{~mol}^{-1}$. The residual activity after prolonged heating $\left(A_{\infty}\right)$ was $\sim 62 \%$ of the total PME activity. Figure 10B illustrates the thermal inactivation curves of pepper $\mathrm{PME}$ in a temperature range from 58 to $70{ }^{\circ} \mathrm{C}$. The thermal inactivation of pepper $\mathrm{PME}$ at $\mathrm{pH} 7.5$ in this temperature range exhibits a biphasic model, indicating the presence of a heat-labile and a heat-resistant fraction of PME, both showing first-order inactivation mechanisms. Labile and resistant forms of PME have been shown to occur in a number of other fruits and vegetables including oranges $(18,31,32)$, grapefruits (33), sweet cherries (8), persimmon (9), tomatoes (28), and green beans (34). At the higher temperatures, the inactivation of the heat-labile fraction proceeds very quickly so that the inactivation rate constants cannot be accurately estimated. The activity and the inactivation rate constants of the stable fraction were estimated using nonlinear regression

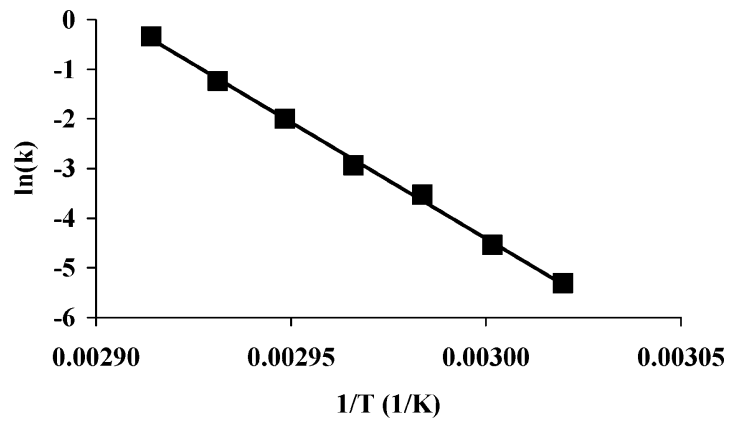

Figure 11. Temperature dependence of inactivation rate constant for thermal inactivation of the thermostable fraction of purified pepper PME.

analysis and the activation energy using linear regression analysis (Table 2). Purified pepper PME, like carrot PME, is less stable toward thermal treatment when compared to other PMEs from different sources. The inactivation rate constant for the labile and stable PME fraction of purified pepper PME at $60{ }^{\circ} \mathrm{C}$ were, respectively, 0.8084 and $0.0107 \mathrm{~min}^{-1}$, and that for the stable PME fraction at $70{ }^{\circ} \mathrm{C}$ was $0.7161 \mathrm{~min}^{-1}$. LyNguyen et al. (12) reported a $k_{60}{ }^{\circ} \mathrm{C}=0.6814 \mathrm{~min}^{-1}$ for purified carrot PME, whereas Anthon and Barret (35) obtained 0.654 and $0.684 \mathrm{~min}^{-1}$ for carrot juice, considering as reference temperatures 65 and $70{ }^{\circ} \mathrm{C}$, respectively. The thermostable pepper PME fraction contributed $\sim 57 \%$ of the total activity. The inactivation rate constants of the thermostable fraction increase with increasing temperature. The Arrhenius plot for the thermal inactivation of the thermoresistant fraction in the temperature range of $58-70{ }^{\circ} \mathrm{C}$ (Figure 11) showed a linear behavior $\left(r^{2}=0.998\right)$ and yielded an activation energy of 388.9 $\mathrm{kJ} \mathrm{mol}^{-1}$. This value is in the same range found for commercial orange PME, 301.4-350.5 $\mathrm{kJ} \mathrm{mol}^{-1}$ (19), but higher than the one found by Ly-Nguyen et al. (12) for purified carrot PME $\left(289.2 \mathrm{~kJ} \mathrm{~mol}^{-1}\right)$.

\section{LITERATURE CITED}

(1) Doesburg, J. Pectic Substances in Fresh and Preserved Fruits and Vegetables; IBVT Communication 25; Wageningen, The Netherlands, 1965.

(2) Jen, J. J.; Robinson, M. L. Pectolytic Enzymes in Sweet Bell Peppers (Capsicum annuum L.). J. Food Sci. 1984, 49, 10851087.

(3) Gross, K. C.; Watada, A. E.; Kang, M. S.; Kim, S. D.; Kim, K. S.; Lee, S. W. Biochemical changes associated with the ripening of hot peppers fruit. Physiol. Plant. 1986, 66, 31-36.

(4) Sethu, K. M. P.; Prabha, T. N.; Tharanathan, R. N. Post-harvest biochemical changes associated with the softening phenomenon in Capsicum annuum fruits. Phytochemistry 1996, 42, 961-966.

(5) Castaldo, D.; Quaglivolo, L.; Servillo, L.; Balestrieri, C.; Giovane, A. Isolation and characterization of pectin methylesterase from apple fruit. J. Food Sci. 1989, 54, 653-5.

(6) Lin, T. P.; Liu, C.-C.; Chen, S.-W.; Wang, W.-Y. Purification and characterization of pectinmethylesterase from ficus awkeotsang makino achenes. Plant Physiol. 1989, 91, 1445-1453.

(7) Giovane, A.; Quagliuolo, L.; Servillo, L.; Balestrieri, C.; Larata, B.; Loiudice, R.; Castaldo, D. Purification and characterization of three enzymes of pectin methylesterase from tomato fruit. $J$. Food Biochem. 1994, 17, 339-349.

(8) Alonso, J.; Rodriguez, T.; Canet, W. Purification and characterization of four pectinesterases from sweet cherry (Prunus avium L.) J. Agric. Food Chem. 1996, 44, 3416-3422.

(9) Alonso, J.; Howell, N.; Canet, W. Purification and characterization of two pectinesterases from persimmon (Dyospyros kaky) J. Sci. Food Agric. 1997, 75, 352-358. 
(10) Denès, J.-M.; Baron, A.; Drilleau, J.-F. Purification, properties and heat inactivation of pectin methylesterase from apple (cv. Golden Delicious) J. Sci. Food Agric. 2000, 80, 1503-1509.

(11) Ly-Nguyen, B.; Van Loey, A.; Fachin, D.; Verlent, I.; Indrawati; Hendrickx, M. Purification, characterization, thermal and highpressure inactivation of pectin methylesterase from bananas (cv. Cavendish). Biotechnol. Bioeng. 2002, 78, 683-691.

(12) Ly-Nguyen, B.; Van Loey, A.; Fachin, D.; Verlent, I.; Indrawati; Hendrickx, M. Partial purification, characterization and thermal and high-pressure inactivation of pectin methylesterase from carrots (Daucus carrota L.). J. Agric. Food Chem. 2002, 50, 5437-5444.

(13) Heuskeshoven, J.; Dernick, R. Simplified method for silver staining of proteins in polyacrylamide gels and the mechanism of silver staining. Electrophoresis 1985, 6, 103-112.

(14) Eagerman, B. A.; Rouse, A. H. Heat Inactivation temperaturetime relationships for pectinesterase inactivation in citrus juices. J. Food Sci. 1976, 41, 1396-1397.

(15) Ramesh, M. N.; Sathyanarayana, K.; Girish, A. B. Biphasic model for the kinetics of vegetable cooking at $100{ }^{\circ} \mathrm{C}$. J. Food Eng. 1998, 35, 127-133.

(16) Indrawati; Van Loey, A. M.; Ludikhuyze, L. R.; Hendrickx, M. E. Lipoxygenase inactivation in green beans (Phaseolus vulgaris L.) due to high-pressure treatment at subzero and elevated temperatures. J. Agric. Food Chem. 2000, 48, 1850-1859.

(17) Indrawati; Van Loey, A. M.; Ludikhuyze, L. R.; Hendrickx, M. E. Single, combined, or sequential action of pressure and temperature on lipoxygenase in green beans (Phaseolus vulgaris L): a kinetic inactivation study. Biotechnol. Progress 1999, 15, 273-277.

(18) Van den Broeck, I.; Ludikhuyze, L.; Van Loey, A. M.; Weemaes, C. A.; Hendrickx, M. E. Inactivation of orange pectin methylesterase by combined high-pressure and temperature treatments: a kinetic study. J. Agric. Food Chem. 2000, 48, 19601970.

(19) Van den Broeck, I.; Ludikhuyze, L.; Van Loey, A. M.; Weemaes, C. A.; Hendrickx, M. E. Thermal and combined pressuretemperature inactivation of orange pectin methylesterase: influence of pH and additives. J. Agric. Food Chem. 1999, 47, 29502958.

(20) Van den Broeck, I.; Ludikhuyze, L.; Van Loey, A. M.; Weemaes, C. A.; Hendrickx, M. E. Thermal inactivation kinetics of pectinesterase from oranges. J. Food Process. Preserv. 1999, 23, 391-406.

(21) Pressey, R.; Avants, J. K. Multiple forms of pectinesterases in tomatoes. Phytochemistry 1972, 11, 3139-3142.

(22) Markovič, O.; Obendorf, R. Soybean seed pectinesterase. Seed Sci. Res. 1998, 8, 455-461.

(23) Rexová-Benková, L.; Markovič, O. Pectic Enzymes. Adv. Carbohydr. Chem. Biochem. 1976, 33, 323-385.
(24) Yemenicioğlu, A.; Cemeroğlu, B. Separation and thermal characterization of ionically and tighly cell-wall-bound pectin methylesterase from cucumbers (Cucumis sativus). Z. Lebensm. Unters. Forsch. A 1999, 208, 369-372.

(25) Korner, B.; Zimmermann, G.; Berk, Z. Orange pectinesterase: purification properties and effect on cloud stability. J. Food Sci. 1980, 45, 1203-1206.

(26) Lee, Y. S.; Wiley, R. C. Measurement and partial characterization of pectinesterase in apple fruits. J. Am. Soc. Hortic. Sci. 1970, 95, 465-468.

(27) Puri, A.; Solomons, T.; Kramer, A. Partial purification and characterization of potato pectinesterase. Food Chem. 1982, 8 , 203-213.

(28) Crelier, S.; Tâcher, M. C.; Raemy, A.; Renken, A.; Raetz, E. High-pressure for the inactivation of enzymes in food products: thermal and HHP treatment of tomato pectin methylesterase. Poster presentation at the 9th World Congress on Food Science and Technology, Budapest, Hungary, 1995.

(29) Fachin, D.; Van Loey, A. M.; Ly-Nguyen, B.; Verlent, I.; Indrawati; Hendrickx, M. Comparative study of the inactivation kinetics of pectinmethylesterase in tomato juice and purified form. Biotechnol. Prog. 2002, 18, 739-744.

(30) Seyderhelm, I.; Boguslawski, S.; Michaelis, G.; Knorr, D. Pressure induced inactivation of selected food enzymes. J. Food Sci. 1996, 61, 308-310.

(31) Versteeg, C.; Rombouts, F. M.; Spaansen, C. H.; Pilnik, W. Thermostability and orange juice cloud destabilizing properties of multiple pectinesterases from oranges. J. Food Sci. 1980, 45, 969-971, 998.

(32) Wicker, L.; Temelli, F. Heat inactivation of pectinesterase in orange juice pulp. J. Food Sci. 1988, 53, 162-164.

(33) Seymour, T. A.; Preston, J. F.; Wicker, L.; Lindsay, J. A.; Wei, C.; Marshal, M. R. Stability of pectinesterases of Marsh whit grape fruit pulp. J. Agric. Food Chem. 1991, 39, 1075-1079.

(34) Laats, M. M.; Grosdenis, F.; Recourt, K.; Voragen, A. G. J.; Wichers, H. J. Partial purification and characterization of pectin methylesterase from green beans. J. Agric. Food Chem. 1997, $22,5572-5577$.

(35) Anthon, G. E.; Barret, D. Kinetic parameters for the thermal inactivation of quality-related enzymes in carrots and potatoes. J. Agric. Food Chem. 2002, 50, 4119-4125.

Received for review October 17, 2003. Revised manuscript received June 23, 2004. Accepted June 23, 2004. S.M.C. gratefully acknowledges financial support from the Fundação para a Ciência e Tecnologia (Grant BD/6642/2001), the Fund for Scientific research-Flanders, and the research council of the Katholieke Universiteit Leuven.

JF0352071 